\title{
A Story about Time Travel - The Story of Chinese Characters (0181- 0195) When Translated on Korean Pronunciation
}

\author{
Hyeonhi Regina Park ${ }^{1}$, Jiah Anna Kim², Rosa Kim ${ }^{3}$, Alain Hamon ${ }^{4}$, Sohwa Therese Kim ${ }^{5}$, Sangdeog \\ Augustin $\mathrm{Kim}^{6 *}$ \\ ${ }^{T}$ Department of Elderly care and welfare, Joongbu University, Kumsan, Republic of Korea (ROK) \\ ${ }^{2}$ Department d'Expertise economique, Universite de Paris-Est Creteil, Paris, France \\ ${ }^{3}$ Specialite d'Economie politique, Ecole des Hautes Etudes en Sciences Sociales (EHESS), Paris, France \\ ${ }^{4}$ L'Ecole Internationale Jean-Mermoz, Abidjan, Cote d'Ivoire \\ ${ }^{5}$ Department of French language and literature, Seoul Women's University, Seoul, ROK \\ ${ }^{6}$ Department of Companion animal and animal resources science, Joongbu University, Kumsan, ROK
}

*Corresponding Author

Sangdeog Augustin Kim

\section{Article History}

Received: 09.03.2020

Accepted: 17.03 .2020

Published: 23.03.2020

\begin{abstract}
How were the Chinese characters made? Chinese characters have been created by Chinese people on Shang dynasty. Now it is difficult to know the making method. Because the distant of time is more than 3000 years. It is too long for the people to understand the method. Though the trial of analyze is not easy, there is one method. It is the imagination through time travel; a story about time travel. The present researchers collected 15 Chinese character by random and named them as (0181-0195). The researchers separated each Chinese character into several parts, and tried to find out the pronunciation of the characteristic parts. For example, Zeong Ga(a family; 庭家). The meaning of family, (Zeong Ga; 庭家), in the Chinese character is composed of two things; "This is the very thing that I have for long time searched!" and "I do this thing in the first time!"
\end{abstract}

Keywords: A story about time travel, How were the Chinese characters made?, The meaning of family, Zeong Ga( 庭家), "This is the very thing that I have for long time searched!".

\section{INTRODUCTION}

It is known that Tcheonzamun (The thousand character essay) poems were understood well through Korean pronunciation [1], and some Chinese characters also were analyzed through same method of Korean pronunciation [2]. The success of the traduction or the analyse of Chinese characters through Korean pronunciation, it may be uncertain. However, it is not absurd. Because it was possible to analyze some of them through Korean pronunciation [2].

How were the Chinese characters made?. It is written that Chinese characters have been created by Chinese people on Shang dynasty [3]. Now it is difficult to know the making method. Because the distant of time is more than 3000 years. It is too long for the people to understand the method. Though the trial of analyze is not easy, there is one method. It is the imagination through time travel; a story about time travel. Both Koreans and Chinese people have commonly used the Chinese character [4].

\section{Materials ANd Methods}

The present researchers collected 15 Chinese character by random and named them as (0181-0195). The researchers separated each Chinese character into several parts, and tried to find out the pronunciation of the characteristic parts. Here, there are two pronunciations for the part; the first is Korean pronunciation of the part (from the

Copyright @ 2020: This is an open-access article distributed under the terms of the Creative Commons Attribution license which permits unrestricted use, distribution, and reproduction in any medium for non commercial use (NonCommercial, or CC-BY-NC) provided the original author and source are credited. 
next example, Gon $(/ /)$ and myeog $(\neg)$ ), and the second is Korean meaning of the part (from the next example, doyazi( 范 ) ).

0182-2) "Ga(家) = Gon $(I)+$ myeog $(\neg)+$ doyazi $($ 芜 $)=\underline{\text { Gon }}+$ myeog + doyazi $=$ G yeo ya $=$ Gyeoya $\rightarrow I$ geoya! $\rightarrow$ Ga."

And then, the present researchers assembled the pronunciations in order to find out some valuable meaning in the Korean language. Here, 'I geoya!' means "This is the very thing that I have searched for long time!".

\section{RESUlTS AND DISCUSSION}

The present researchers have found some results for 15 Chinese characters (0181-0195). Nearly all of 15 letters were analyzed, and the next is the results.

Number, Korean Pronunciation of the Chinese character (meaning in Korean language; Chinese character) = Korean pronunciation of each part of the Chinese character (Chinese character) = Brief part of Korean pronunciation in English $=$ Assembled word $\rightarrow$ Changed word; Korean alphabet.

$0181 \mathrm{Zo}($ 兆)(2): This is the second interpretation of this Chinese character.

This word of 'Zwoyo zwoyo!' expresses in Korean language "Give me the thing, give me the thing!"

"Zo(the symptoms; 兆) $=\mathrm{Zu}($ the spark; \) + byeol(the ascending rightward; $ノ)+$ gon(to set a perpendicular stroke; I ) + zu(the spark; \) + byeol(the ascending rightward; J ) + gon(to set a perpendicular stroke; I ) = $\underline{Z} \mathrm{u}+$ byeol + gon $+\underline{\text { zu }}+$ byeol + gon $=$ Z yeo o z yeo o $=$ Zyeoo zyeoo $\rightarrow$ Zwoyo zwoyo $! \rightarrow$ Zo."

$0182 \mathrm{Ga}$ (家)(3): This is the third interpretation of this Chinese character.

0182-1) $\mathrm{Ga}($ 家 $)=$ Gon(a perpendicular stroke; I ) + deobneun(to cover; $\neg)+$ doyazi(pig; 豕) = Gon + deobneun + doyazi $=$ G eo ya $=$ Geoya $\rightarrow$ Ga."

0182-2) 'I geoya!' means "This is the very thing that I have searched for long time!"

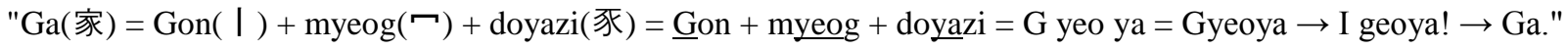

0183 Zeong(庭):

'I tcheoeumin!' means "I do this thing for the first time!"

"Zeong $($ garden; 庭) $=$ Il(number one; - ) + tcheon(number thousand; 千 $)+$ eom(dugout hut; 广) + in(walk for long distance; 子 $)=\underline{\mathrm{Il}}+\underline{\text { tcheon }}+\underline{\text { eom }}+\underline{\mathrm{in}} \rightarrow$ I tcheo eum in $\rightarrow$ I tcheoeumin $! \rightarrow$ Zeong.

0184 Zeong Ga(庭家):

Zeong(庭): 'I tcheoeumin!' means "I do this thing in the first time!"

"Zeong(garden; 庭) = Il(number one; 一) + tcheon(number thousand; 千 $)+$ eom(dugout hut; 广) + in (walk for long distance; 及) $=\underline{\mathrm{Il}}+\underline{\text { tcheon }}+\underline{\text { eom }}+\underline{\text { in }} \rightarrow$ I tcheo eum in $\rightarrow$ I tcheoeumin $! \rightarrow$ Zeong."

Ga(家): 'I geoya!' means "This is the very thing that I have for long time searched!"

"Ga(the home; 家) = Gon(a perpendicular stroke; I ) + myeog(to cover; $\neg)+$ doyazi(the pig; 豕) $=$ Gon + myeog + doyazi $=$ G yeo ya $=$ Gyeoya $\rightarrow$ I geoya $\rightarrow$ Ga."

Zeong Ga(a family; 庭家): The meaning of family in the Chinese character is composed of two things; "This is the very thing that I have for long time searched!" and "I do this thing in the first time!".

$0185 \operatorname{Sig}($ 食):

"Sig(to eat; 食) = Saram(the human-being; 人) + bbitchida(to ascend rightward; J ) + geutchida(to stop; 艮) $=\underline{\text { Saram }+}$ bbitchida + geutchida $\rightarrow$ S i g $=$ Sig."

0186 Lo (路)(2): This is the second time of this Chinese character.

"Lo(路) $=$ Dali(the foot; 各 $)+\operatorname{zog}($ the foot; 足 $)=$ Dali + zog $\rightarrow$ L o $=$ Lo."

(The present researchers do not have confidence about the pronunciation between 'Dali' and 'Dari'. The researchers decided to use 'Dali'. Because 'Dalida' is used in order to indicate 'To run', so we used 'Dali' as the Korean pronunciation for leg. The reason is that we run with our legs.) 
$0187 \mathrm{Ta}($ 打):

"Ta(You hit someone or something, you beat them very hard; 打) = Batang(the foundation or the base; 才) + sanai (the man; 丁) = Batang + sanai $=$ T a $=$ Ta."

0188 Heui(熙): The meaning of 'Hiii aeu!' is "My son-in law, May I ask a favor of you for my daughter? My daughter is soft-hearted, so she is always smiling. Treat her more and more tender, please!"

"Heui(to shine, to flourish or to be peaceful; 熙) $=$ Hye(to hide or to cover; $\sqsubset)+\sin$ (to set a perpendicular stroke; I ) + ib(the mouth; 口 $)+\sin ($ to set a perpendicular stroke; I ) + baem(the snake; 巳 $)+$ bul (the fire; 火) $=\underline{\text { Hye }+}$ $\underline{\sin }+\underline{\mathrm{i} b}+\underline{\sin }+$ b $\underline{\mathrm{ae}} \mathrm{m}+\underline{\mathrm{b}} \underline{\mathrm{l}} \mathrm{l}=\mathrm{H}$ i i i ae $\mathrm{u}=$ Hiii aeu! $\rightarrow$ Heui."

0189 Hoe(灰):

"Hoe $(\mathrm{ash} ;$ 灰 $)=$ Hwa(the fire; 火 $)+$ hana(number one; -$)+\sin ($ to communicate well; I $)=\underline{\text { Hwa }}+$ hana $+\sin$ $=\mathrm{H}$ a $\mathrm{i}=$ Hai $\rightarrow$ Hoe."

$0190 \operatorname{Tan}($ 炭)(2): This is the second time of this Chinese character. It is strange, but, it is shown that both Korean meaning of this letter and the pronunciation of this Chinese character in Korean language are same. The meaning of Tan( 炭) is 'Being burned(Bul e tan; 불에 탄)' in Korean language.

"Tan $($ charcoal; 炭 $)=$ Tada(to burn; 火 $)+$ han $($ precipice; 厂 $)+\operatorname{san}($ mountain; 山 $)=$ Tada + han + san $=$ Tan."

$0191 \operatorname{Hang}($ 恒):

"Hang (Being always; 恒) = Hana (number one; - ) + maeum(the heart, the mind, the emotion; 小) +

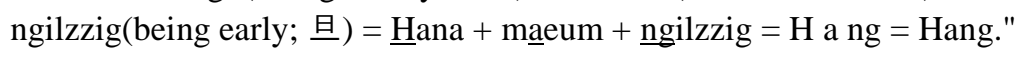

$0192 \mathrm{Go}$ (庫): For this letter $\mathrm{Go}$ (庫), the Korean pronunciation 'Go' and the meaning in Korean language 'Gotzib' is overlapped.

"Go(the storing place for trivial objects; 庫) = Gul bawi(the dugout hut, rock house; 广) + itmom(the rounding part of a tooth in the body; 車) $=$ Gul bawi + itmom $=$ G o $=$ Go."

0193 Pan(板): 'Pyeoeonye' means 'It is comfortable!" or "It is good, very nice!" in Korean language. On the Chinese dictionary of Kangxizidian[5], which was made in the period of Ch'ing dynastry, Pan(板) means the home. And both the Korean pronunciation of this letter and its meaning in Korean language are similar together.

"Pan $($ Boards made of wood; 板 $)=\operatorname{Pal}($ number eight; 八 $)+$ yeol(number ten; 十) + eom(the precipice; Г) +

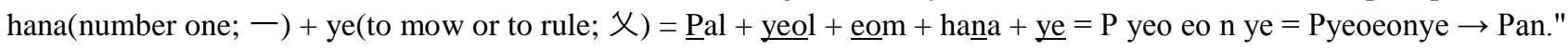

$0194 \mathrm{Zi}($ 紙): Here, 'Zzi' is similar to 'Zzizda', which means in Korean language 'to tear the paper.' "Zi(Paper; 紙) = Zageun $($ small; 幺 $)+$ zageun(small; 小 $)+$ zi(the name of a country in Persia, Central Asia or India) $($ 氏 $)=\underline{\text { Zageun }+}$ zageun + zi $=$ Z z i $=$ Zzi $\rightarrow$ Zi."

0195 Seong(聖)(2): This is the second time of this Chinese character. "Seong(being holy; 聖) = Sa(the learned man; \pm ) + byeol $($ to ascend rightward; J ) + gu(the mouth; $\square)+\mathrm{i}($ the ear; 耳 $)=\underline{\mathrm{Sa}}+$ byeol + gu $+\underline{\mathrm{ng}}=\mathrm{S}$ yeo u ng $=\mathrm{Syeoung} \rightarrow$ Seong."

\section{ACKNOWLEDGEMENTS}

We thank Mr Ilsoo Joseph Kim and Mrs Bohwa Kim, Mr Yeonghag Park and Mrs Hilye Sarah Kim, Ms Jieun Agatha Kim and Mr Kunjoo Daegon-Andrea Kim. We thank Father Jean Blanc and Father Hifumi Iwazaki. We thank the students of Department of Companion Animal and Animal Resources Science in Joongbu University. We thank Mrs Tamako Hayashi and Mr Yoshihiro Hayashi, Mrs and Mr Kuromiya, Mrs Francine Tenaillon and Professor Nicolas Tenaillon, and the members of Daejeon Ludovich of Ordo Franciscanus Saecularis(OFS) and the members of Daejeon Nae-dong Catholic Church, Mrs. Jeomhyeon Carolina Park, Mr Hijeong Aloysius Kim, and Mrs and Mr. Kuromiya.

\section{REFERENCES}

1. Park, H. R., Kim, J. A., Kim, K. D. A., Kim, J. A., Kim, S. T., Kim, R., ... \& Kim, S. A. (2017). Ancient Koreans 
petition to God in Tcheonzamun: The thousand character essay poem (641st to 656th letters). Journal of Languages and Culture, 8(6), 79-84.

2. Park, H. R., Kim, K. D. A., Kim, J. A., Kim, R., Hamon, A., Kim, S. T., \& Kim, S. A. (2019). The Story of Chinese Characters (0031-0040) When Translated on Korean Pronunciation.

3. Fairbank, J. K., \& Reischauer, E. O. (1989). China: tradition \& transformation. Houghton Mifflin College Division.

4. Dallet, C. H. (1874). Histoire de l'Eglise de Corée (History of Korean Catholic Church). Victor Palme. Paris. France, 11-99.

5. Zhang, S. N.(1716). Kangxizidian (Edited by Zhonghua Book Company in 2013). 